\title{
Regional demands for policy participation in the EU multilevel system*
}

\author{
Philipp Studinger, Humboldt-Universität zu Berlin \\ Michael W. Bauer, Humboldt-Universität zu Berlin ${ }^{* *}$
}

\begin{abstract}
Over the past 50 years, an increasing amount of political authority has been delegated to the regional government level in Europe. This paper analyses regional demands for involvement in policy-making by focusing on the preferences of toplevel regional civil servants ("regio-crats"). A survey $(n=347)$ of regio-crats in 60 regions of 5 European Union member states serves as the empirical basis for the analysis of regional demands for policy involvement in the multilevel system. The data reveal differential patterns of demands. By and large, regio-crats emerge as being conservative, incremental and modest in their wishes for greater policy involvement, except where the regional contexts are characterised by substantial emancipatory political ambitions or cultural distinctiveness. Regional demands for policy participation in the multilevel system are pragmatic, patch-worked and incremental, and more conservative than transformative.
\end{abstract}

\section{JEL classification}

D73; H77; R50

\section{Keywords}

subnational bureaucrats; European Union; policy allocation; multilevel system

DOI: https://doi.org/10.17979/ejge.2012.1.1.4274

\footnotetext{
" This paper emerged from the project "Governance Preferences in the European Multilevel System" funded by the German Research Foundation (Grant BA3658/2-1), whose support is gratefully acknowledged. We are indebted to Diana Pitschel for her collaboration in the project and for her input to earlier versions of this paper. We also thank Arjan Schakel and Charlie Jeffery for valuable comments.

* Address for correspondence: Prof. Dr. Michael W. Bauer, Chair of Politics and Public Administration, Humboldt-Universität zu Berlin, Institute of Social Sciences, Unter den Linden 6, D-10099 Berlin, e-mail: mw.bauer@sowi.hu-berlin.de.
} 


\section{Introduction}

Over the past 50 years, regions - and especially those in today's European Union - have been entrusted with ever greater political authority (Hooghe et al. 2010). However, notwithstanding the growing political importance of regions, we know very little about the elites who run these subnational political structures, who shape regional political decisions and implement political programmes. The aim of this paper is twofold. First, we want to help fill this research gap by focussing on the preferences of top-level regional civil servants ("regio-crats"). Second, we put centre stage the question of the role of regions in the European multilevel governance context. In particular, two questions are raised: What explains regiocrats' preferences regarding involvement in policy-making (by their respective regions) in the multilevel system and, do we need regional-level variables in order to conduct a satisfying analysis of subnational preferences regarding vertical competence allocation?

The questions we raise are of interest to those who study regions as agents of ongoing transformation of states and the rise of multilevel political orders, in general, and also to those investigating the regions of the European Union, in particular. We look for patterns in the regio-crats' preference variations and suggest explanations for them. In order to answer our research questions, we conducted a survey among top-level subnational officials in five European countries and asked them about their preferences with respect to competence for their regions in twelve policy areas.

Our quest for explanations is based on a view on socio-economic, political and cultural aspects of regional authorities. We believe that there is a link between the beliefs and attitudes of regio-crats (especially those at the top of their organisations) and the political structures for which they work. The individual within certain range - can choose his actions and does so strategically with view of his self-interests. But he is also shaped by and thus embodies the way his organisation interprets outside reality. ${ }^{1}$ Moreover, by working in an institution an individual himself becomes the bearer of the norms, scripts and standard assessments of the collectivity he represents (Egeberg 2004). ${ }^{2}$ Under this assumption, we argue that the preferences of regio-crats represent a general estimate of subnational political ambitions to participate in the European multilevel governance system.

The paper is structured as follows. In Section 2, we present competing approaches (individual, functional, national and regional) for how best to explain regio-crats' preferences regarding policy competence allocation in multilevel constellations. Section 3 describes the survey we conducted and outlines the operationalisation of the explanatory approaches. The statistical analysis follows in Section 4, while Section 5 presents the conclusions drawn on the basis of our findings. As the analysis will show, we find a number of regional variables that are persistently significant across several different models. In particular, the variables concerning the cultural distinctiveness, institutional endowment and socioeconomic performance of regions stand out. In addition, the analysis shows that the personal opportunities of regio-crats influence their preferences regarding greater policy competence at the regional level.

\footnotetext{
${ }^{1}$ The use of male pronouns throughout the text is for ease of reading only and should be taken to refer to either gender.

${ }^{2}$ Institutionalists argue that "members of an institution observe and are the guardians of its constitutive principles and standards" and that their behaviour is based on a "logic of appropriateness and a sense of obligations and rights derived from an identity, role, or membership in a political community and the ethos and practices of its institutions" (Olsen 2009: 9)
} 


\section{Underlying Assumptions}

Before we elaborate on our theoretical models and begin the descriptive and analytical analyses, a word about the subnational data on which they are based seems in order. It is extremely difficult to acquire this kind of data, especially if it is to be suitable for cross-national comparisons. Usually, the researchers who are interested in subnational issues will have to obtain it themselves, which, in fact, was also the case for this study (details below). More concretely, our dependent variables are based on data illustrating the attitudes of regio-crats. Attitudinal data relating to elites in general have both strengths and weaknesses, and so do our subnational elite data. That is, individuals who work in the upper echelons of subnational authorities and have direct links to the political sphere probably form their preferences under different conditions than does the broader, generally less well-informed and less well-trained national public. One can thus assume that regio-crats, with their particular expertise and their routine familiarity with the regional political universe, hold views which (especially with respect to core topics related to their respective political entities) are different, more reliable and more coherent than those of the general public in their regions.

Our research question is the following: What explains regio-crats' attitudes concerning competence allocation in the multilevel system? In other words, what are the factors, with respect to a range of predefined policy areas, that lead regiocrats to desire codetermination rights? The standard explanatory factors found in the literature are based on the concepts of individual utility, contextual variables and functionality (Hooghe 2001; Loveless and Rohrschneider 2008). We test these standard programmes, focusing, in particular, on the regional context. Factors that reflect the regional context are summarised under an explanatory programme based on regional social identity. We want to see whether and under which conditions such regional factors have an added value in their own right in explaining differences in preferences regarding regional participation in the European multilevel governance system (Pitschel 2012). We now turn to these explanatory programmes.

\section{The Individual Opportunity Approach}

The first explanatory programme is strongly related to the utility calculus. It argues that individuals calculate the respective impacts of different options on their personal opportunity structures. As a consequence, when faced with a choice, individuals will favour the option they believe will lead to a higher personal pay-off (Thielemann 2004: 367). Other studies have shown that individual opportunity structures - especially in the case of bureaucrats - are driving forces behind preference formation (Niskanen 1971; Dunleavy 1985; Searing 1991, 1994).Regarding the question of regional authorities' policy competences, we argue that top-level subnational bureaucrats will desire the allocation of competences to the regional level if they expect some gain for themselves.

It is difficult to define the actual utility that might be involved. On the one hand, rational-choice research refers exclusively to tangible goods that are directly available to the individual (Kato 1996). Accordingly, financial incentives should be the driving force behind preference formations (Hooghe 2001). On the other hand, public-administration research often uses a broader conceptualisation of an individual's utility. In this context, the commodity to be maximised does not refer exclusively to the individual but also to his social context (Levi 1997). In other words, tangible as well as non-financial goods - such as the prestige or power of a region - might play a role in the formation of subnational administrators' preferences. 
Applying such a broad concept of utility would obviously be problematic, because all manner of motives and factors that somehow relate to a utility consideration could be included. ${ }^{3}$ We thus follow the narrow conceptualisation of utility and consider only those aspects that are directly related to the amendment of the subnational administrators' positions. Research on the motivations of publicadministration personnel has demonstrated that administrative elites are basically motivated in their career prospects and their opportunities for advancement (Searing 1994: 19; Hooghe 2001: 21). Regio-crats compete for leverage in designing policies. The more competences the regional level of authority has, the higher this leverage. In sum, the opportunity approach argues that regio-crats will desire more regional policy competences whenever they perceive that this would enhance their individual situations.

\section{The Functionality Approach}

The second explanatory programme concerns the nature of policies themselves. Recent studies find that functionality is an influential factor when the allocation of competences is examined (Schakel 2009). Similarly, Hooghe's study (2003) on top-level officials in the European Commission and in national administrations demonstrates that political elites are guided by functional considerations when they are asked which policies should be regulated at the supranational and which at the national level. The issue of functionally efficient policy allocation is debated in the literature on fiscal federalism. ${ }^{4}$ Oates' theorem states that, in the absence of problems of redistribution and negative external effects, policies should be allocated at the lowest possible hierarchy level (Oates 1999: 1122). In addition, although economies of scale might push the provision of most public goods and services towards the national (or even higher) political levels, possible heterogeneity of local preferences, which would pull allocation of competences to subnational levels, also has to be considered. Especially because detailed information about local diversity (which would be needed to design efficient policy solutions) is difficult to obtain and to process centrally, efficient (i.e., functional) allocation of competences is usually not quite as central as the functionality paradigm might seem to predict at first sight (Hooghe and Marks 2005).

Concerning regio-crats, we can assume that they come with special knowledge about these characteristics of the different policies. In consequence, it is plausible to argue that they are able to roughly rate the efficiency of different options regarding policy competence allocation. In sum, if top-level subnational bureaucrats base their preferences regarding policy competences for regions on a rationale of functionality, then they should favour policy competences for subnational entities only if regulation at this level of authority is functionally efficient.

\section{The Subnational Social Identity Approach}

The explanatory programme we call the subnational social identity approach sees the affiliation of individuals to socially defined groups as an important factor in the formation of preferences (McLaren 2002; Diez Medrano 2003; Scully and Farrell 2003; Thielemann 2004; Hooghe and Marks 2005; van Esch 2006; de Vries and van Kersbergen 2007). Individuals form and orient their preferences in line with the norms and values of their own social groups. It is clear that subnational administrators are part of the socially defined group of the region to which they belong and for which they work. Since they hold top-level positions within their

\footnotetext{
${ }^{3}$ For a detailed discussion of this question, and for theoretical arguments, see Pitschel (2012).

4 "The main analytical task for fiscal federalism has been to define the appropriate assignment of allocative responsibilities to decentralised government levels and matching revenue sources" (Bird et al. 2002: 416).
} 
regional administrations, they prepare, design and implement policies and political decisions and consequently are familiar with the political interests of their region. In consequence it is plausible to assume that the interests and preferences of regions' institutions are a primary focus of the regional administrators. ${ }^{5}$

According to the social identity approach, top-level bureaucrats should pursue the interests of their own regions and internalise regional preferences concerning political issues. Before we can analyse the desire for subnational policy competences, we first need information about regional ambitions regarding these competences. We can draw on the literature on subnational mobilisation that discusses policy-making processes (Hooghe 1995; Jeffery 1996, 2000; Tatham 2008) to find explanatory factors for the emancipatory efforts of regions. Because the endowment of regions with policy competences reflects one aspect of emancipatory aspirations, we can use these same factors in order to determine subnational preferences. Generally, we argue that regions seeking to enhance their political profile will want to expand their political competences.

One important factor discussed in the subnational mobilisation literature is the socioeconomic situation of regions (Bookman 1992; Harvie 1994; Marks et al. 1996). However, there is disagreement about the actual direction of this relationship. On the one hand, socioeconomically strong regions want to gain some independence from central government and assume competence for certain policies (Gourevitch 1979). On the other hand, socioeconomically weak regions are also believed to have an incentive to take matters into their own hands with a view to advancing their economic development independently of the nation state (Hechter 1975; Fearon and van Houten 2002).

Another factor that influences the emancipatory potential of a region is its cultural distinctiveness. Subnational authorities that deviate from the national population with respect to ethnic or religious characteristics are culturally distinct from the nation state. This regional identity induces the desire to safeguard selfdetermination (Esman 1977; Connor 1994; Keating 1998; Alesina and Spolaore 2003; Björklund 2006; Brancati 2006). Therefore, subnational entities that are culturally distinct from the nation state should be interested in holding competence with respect to many policies. Third, party-political competition is believed to influence subnational demands for autonomy (van Houten 2003, 2009). In particular, an incongruence in the composition of the governmental coalition between the regional and national levels might produce disagreement in policymaking and consequently stimulate the desire for policy competences among regional elites.

Finally, the institutional setting of subnational authorities - also discussed in the mobilisation literature - also has to be taken into account. On the one hand, regions that are already institutionally well endowed are argued to be more active promoters of policies. The less restricted subnational authorities are with respect to their policy engagement, the greater their (potential) scope for development. On the other hand, the status quo of regional competences should be a good predictor of desire for competence allocation because the current setting to some extent determines the possibility of increased allocation. In other words, the degree of constitutionally defined regional autonomy should be correlated with the amount of policy competence desired by regio-crats.

\footnotetext{
${ }^{5}$ We take some comfort from the findings of the CANS project (Citizenships After the Nation State). The team around Charlie Jeffery, Ailsa Henderson and Roland Sturm find in their regional population suvey broad support for regional authority. See http://www.institute-ofgovernance.org/major_projects/citizen_after_the_nation_state citizens' and Oberhofer et al. 2011.
} 
To sum up, the social identity approach assumes that regio-crats' preferences are influenced by specific characteristics of the regions they work for. In short, the greater the emancipatory potential of a region, the more competences for their region the elites should favour. Table 1 summarises our three candidate explanatory programs.

Table 1: Explanatory approaches and respective hypotheses

\begin{tabular}{ccc}
\hline $\begin{array}{c}\text { Explanatory } \\
\text { approach }\end{array}$ & Hypothesis & Dependent variable \\
\hline $\begin{array}{c}\text { Individual } \\
\text { opportunity }\end{array}$ & $\begin{array}{c}\text { Regio-crats should desire more regional policy } \\
\text { competences if they expect a positive impact on their } \\
\text { individual situation. }\end{array}$ & \\
$\begin{array}{c}\text { Functional } \\
\text { criteria }\end{array}$ & $\begin{array}{c}\text { Regio-crats should favour policy competences for the } \\
\text { regions if regulation at this level of authority is } \\
\text { functionally efficient. }\end{array}$ & $\begin{array}{c}\text { Regio-crats' preferences } \\
\text { regarding regional policy } \\
\text { competences }\end{array}$ \\
$\begin{array}{c}\text { Subnational } \\
\text { social identity }\end{array}$ & $\begin{array}{c}\text { Regio-crats should desire more regional policy } \\
\text { competences if they belong to a region with a high } \\
\text { emancipatory potential. }\end{array}$ & \\
\hline
\end{tabular}

Source: Authors' compilation.

\section{Research Design}

In order to test for the territorial effect on regio-crats' preferences regarding policy allocation, we make use of a survey addressed to subnational administrative elites concerning their attitudes about different aspects of European integration and governance. We defined the subnational units we are interested in as political authorities which are located directly below the national level and have an elected assembly. ${ }^{6}$ The selection of interviewees - high-ranking officials in subnational administrations - was carried out in several stages.

First, we had to decide which European member states should be included in the survey. Our aim was to ensure that the sample would feature interviewees from states with different institutional settings (decentralised and federal states). We also wanted to include entities with differences in their experience with the European integration process. We assumed that the older member states would have already consolidated their governance structures in the context of European integration. Thus, we decided to interview regio-crats in Germany, Spain, France, Poland, and Hungary comprehending old and new member states as well as decentralised and federal states.

Second, the selection of the subnational units was guided by the consideration of including interviewees with distinct regional backgrounds. In order to increase the variety at the regional level and to ensure that we have variance on the explanatory variables, three factors were of major importance: the socioeconomic status of the interviewees' respective regions, and their cultural and party-political incongruence with respect to the centre (the nation state). Such aspects had been theoretically conceived as potential explanatory factors. Hence, we ensured that both socioeconomically poor and rich regions, regions with and without cultural specificities, and regions with the same and with different governing parties compared to the party-political constellation at the centre were all represented (Marks et al. 1996; Keating 2008). ${ }^{7}$

Third, the final criterion for the selection of the individuals was their position within the subnational administration. We focussed exclusively on heads of unit with policy responsibilities (cf. Bauer 2008) because these are assumed to be the

\footnotetext{
${ }^{6}$ This definition is similar to that of Marks et al. (1996).

${ }^{7}$ For a full list of the subnational authorities included in the survey, see Table 7 in the Appendix. The numbers of enclosed regions differ by country as a consequence of the size of the regional administrative body.
} 
"backbone" of the subnational administrations. High-ranking civil servants generally started their careers within their respective subnational administrations. They hold their positions for a long time and usually demonstrate a high degree of identification with the political unit for which they work. They are equally knowledgeable with respect to the technical requirements of a dossier and with the political constellation surrounding it (Bauer 2008).

Out of the initial sample, we randomly selected the interviewees for each region in each member state. However, due to the varying size and the diverging responsibilities of the regions represented, the numbers of interviewees per region ranged from 1 to 13. Altogether, the sample consisted of 347 individuals in 60 regions (see Table 2). We developed a standardised questionnaire of about 100 (mostly closed) questions. Telephone interviews were conducted by specially trained native speakers in 2007 and $2008 .^{8}$

Table 2: Sample structure

\begin{tabular}{ccccc}
\hline Country & $\begin{array}{c}\text { Regions included in } \\
\text { sample }\end{array}$ & $\begin{array}{c}\text { Interviews per } \\
\text { region }\end{array}$ & $\begin{array}{c}\text { Interviews per } \\
\text { country }\end{array}$ & Response rate \\
\hline Germany & 13 Länder (of 16) & $4-9$ & 78 & $47 \%$ \\
Poland & 12 Voiwodships (of 16) & $2-9$ & 70 & $45 \%$ \\
Hungary & 19 Megyek (of 19) & $2-7$ & 84 & $41 \%$ \\
France & 10 Régions (of 26) & $1-13$ & 66 & $45 \%$ \\
Spain & 6 Autonomous & $5-11$ & 49 & $53 \%$ \\
Total & Communities (of 17) & & 347 & \\
\hline
\end{tabular}

Source: Authors' compilation.

Our dependent variable is the regio-crats' preferences regarding the participation of the subnational level in twelve policy areas in the European multilevel system. ${ }^{9}$ We thus asked top-level subnational bureaucrats to decide whether or not regional authorities should be involved in policy-making across a range of twelve specific policy areas. ${ }^{10}$ We constructed an additive index ranging from 0 (no regional competence) to 12 (competence regarding all policies under study). An even more detailed analysis is possible if we distinguish between policies which are regulated in a functionally efficient manner at the regional level and those which are not. However, we need an objective benchmark in order to evaluate whether or not a particular policy is regulated efficiently at the subnational level. Such a benchmark does not exist, however, or where researchers have developed something of this nature, it is unsuitable for application to the policy categories we chose for our study. ${ }^{11}$ We adopt a second-best solution for our problem by following fiscal federalism arguments and then deducing implications for the subnational level. In essence, we assess whether the scope and externalities of policies are decisive parameters for ascertaining whether a certain policy can be regulated efficiently at the regional level or not. We derive a yardstick which is explained in more detail in

\footnotetext{
${ }^{8}$ For a sociological overview of this data set of administrative elites and for further information, see Bauer et al. (2010).

${ }^{9}$ Multilevel governance is a complex concept comprising aspects that concern policy competences and also varying modes of coordination and interaction (Benz 2007; Benz and Zimmer 2008; Tömmel 2008) In our project, we limited our analysis exclusively to aspects concerning policy competence allocation.

${ }^{10}$ The twelve policy areas are social affairs, asylum and immigration, foreign affairs and defence, health care and consumer protection, border police and frontier defence, culture and education, agriculture tourism, environmental protection, monetary policy, economic development and structural policy, and research and technology. Note that we do not differentiate between administrative and legislative competences.

${ }^{11}$ Schakel (2009) conducted an expert survey in order to obtain information which authoritative level efficiently regulates in regard to certain policies. However, the categorisation carried out in his study is not applicable in our context as we have different and broader policies under study.
} 
the Appendix. ${ }^{12}$ Based on this distinction, we can derive two other variations of the dependent variable. One concerns the preference for competence allocation at the regional level in regard to policies which are efficiently regulated by subnational authorities, while the other concerns those which are not.

The operationalisation of the opportunity approach is based on individual-level variables which were also collected by means of the survey. ${ }^{13}$ On the one hand, the dummy variable "career ambitions" indicates whether top-level bureaucrats want to advance their career within the regional administration where they work. ${ }^{14}$ The dummy variable "security of employment" (as a motivation for entering the subnational administration) taps into another common aspect of individual utility.

The subnational social identity programme is based on factors that are common in subnational mobilisation research. The variable "regional gdp" (Gross Domestic Product) describes the socioeconomic situation of the regions. The dummy variable "stateless nation" indicates cultural differences between the nation state and the subnational entities. The party-political situation is captured by the opposition variables: if the subnational governmental coalition is partly in opposition at the national level, the variable "partly in opposition" is coded 1 (otherwise 0). If no regional government party is represented in the national government, the variable "completely in opposition" takes the value $1 .{ }^{15}$ Finally, the institutional embeddedness of the subnational authorities is operationalised by an indicator taken from the regional authority index developed by Hooghe et al. (2010). The variable "institutional depth" measures the extent to which a regional government is autonomous as opposed to deconcentrated. ${ }^{16}$

Finally, we include a control variable allocated at the subnational measurement level. The variable "regional population (log)" captures how populous a subnational entity is. In the literature, it is assumed that efficient provision of public goods is determined not only by the characteristics of the policies themselves, but also by the size of the affected group. We argue that, all else being equal, the larger the regional population, the more efficient (or less inefficient) is the regulation of the policy at the subnational level. Because regions differ in regard to their number of inhabitants, we control for this fact. Our list of policies for which subnational administrators can articulate their preferences for codetermination is both rather broad and quite general - for instance, "culture and education" instead of more fine-grained policies, such as "primary schools". This enables us to assume that the handling of our policy categories at the regional level will be more efficient (i.e., more functional) the greater the size of the subnational population. Although this factor picks up on the functionality argument, for methodological reasons we cannot integrate a variable representing the actual functional reasoning of our

\footnotetext{
12 Table 9 in the Appendix provides an overview of the classification of the policies. We argue that policies that are generally characterised by high externalities should be regulated at a higher level. In other words, we believe that in such cases the participation of regional authorities is less functional. This approach might be criticised as a normative and subjective decision. However, in consideration of the fact that we need an objective benchmark which is applicable to our framework, this, in our view, is the most objective and transparent approach possible. Due to problems of endogeneity, we could not justify validating the classification exclusively on the basis of the preferences of the interviewees.

${ }^{13}$ For an overview of the independent variables, the operationalisation, the coding and sources, and the expected sign of the coefficient, see Table 8 in the Appendix.

${ }^{14}$ Table 2 provides an overview of the operationalisation of the variables.

15 The situation where a regional government coalition is completely represented in the central government is the reference group in the quantitative analysis. The aspect of incongruence respectively congruence between the governing coalition at regional and national levels is a categorical variable. Therefore we decided to split the potential situations in three dummy variables.

${ }^{16}$ The variable has a theoretical value range of 0 to 4 . In our data set, "institutional depth" takes on the values of 3 and 4 .
} 
interviewees in the statistical analyses below. ${ }^{17}$ However, we do address the functionality approach by means of a descriptive analysis in the next section. To test whether the factors characterising the different approaches explain the regiocrats' preferences for policy allocation at the regional level, we use a multilevel analysis with random-effects. The individuals constitute the first and the regions the second level of the model. ${ }^{18}$

Table 3: Operationalisation of the explanatory variables

\begin{tabular}{|c|c|c|c|}
\hline $\begin{array}{l}\text { Explanatory } \\
\text { approach }\end{array}$ & Variable & Operationalisation & $\begin{array}{l}\text { Expected } \\
\text { sign }\end{array}$ \\
\hline \multirow{2}{*}{$\begin{array}{l}\text { Individual } \\
\text { Opportunity }\end{array}$} & career ambitions & $\begin{array}{l}\text { Interviewee wants to advance his career } \\
\text { within the subnational administration. }\end{array}$ & + \\
\hline & security of employment & $\begin{array}{l}\text { Interviewee is motivated by the security of } \\
\text { employment within the subnational } \\
\text { administration. }\end{array}$ & + \\
\hline Functionality & & $\begin{array}{c}\text { Number of individual competence } \\
\text { preferences that match with allocation as } \\
\text { functionally efficient for the twelve policies } \\
\text { under study. }\end{array}$ & + \\
\hline \multirow{5}{*}{$\begin{array}{l}\text { Subnational } \\
\text { Social Identity }\end{array}$} & regional gdp & Gross Domestic Product & $-1+$ \\
\hline & stateless nation & $\begin{array}{l}\text { The region is a stateless nation. } \\
\text { Regional governmental coalition is partly }\end{array}$ & + \\
\hline & partly in opposition & $\begin{array}{l}\text { congruent with the national governmental } \\
\text { coalition }\end{array}$ & + \\
\hline & completely in opposition & $\begin{array}{l}\text { Regional governmental coalition is in } \\
\text { opposition at national level. }\end{array}$ & + \\
\hline & institutional depth & $\begin{array}{l}\text { Extent to which a subnational government } \\
\text { is autonomous rather than deconcentrated. }\end{array}$ & + \\
\hline Control & regional population $(\log )$ & The logarithm of the regional population. & + \\
\hline
\end{tabular}

Source: Authors' compilation. Note: For an explanation as to why we do not operationalise the functionality approach, please see footnote 12 .

\section{Empirical Analyses}

Asked whether the subnational level should hold competence regarding twelve policy areas, the average response of regio-crats was in the mid-range, although there was a high standard deviation (see Table 4). In general, the regio-crats we surveyed turned out to be surprisingly reluctant to see regions participating in the multilevel governance system. A comparison of the national mean values for competence allocation at the regional level reveals variation in the preferences for subnational participation within our sample. First, we observe differences across countries. Hungarian top-level subnational bureaucrats do not see a need for

\footnotetext{
${ }^{17}$ In our descriptive analysis, we assess with respect to how many policies the individuals' preferences are in line with functionally efficient policy allocation. However, if we included such an independent variable in the regression analysis, we would explain the dependent variable by means of a part of a modified dependent variable.

${ }^{18}$ A potential objection to this research strategy might be the choice of the statistical model. We do not use dummy variables for the countries in order to control for country-specific factors, rather we emphasise the individual and the regional levels. Given that we integrate several (potential) explanatory factors measured at the subnational level, we risk falling into the trap of multicollinearity. We also use an indicator capturing the institutional setting in the nation states.

19 The variable is based on a survey question: "Which professional position would you like to have reached in 5-10 years? That is, other or same position in the regional administration in a national ministry, in the EU administration?" Whenever the interviewee indicated that he sought to reach a higher position in the administration, the variable "career ambitions" is coded "1" otherwise "0".

20 The information is based on a survey question: "Why do you have chosen to work in the administration of a region? Please tell me the most important reason." The answer options had been secure job, proximity to residence, good salary, good career prospects, interesting working area, would like to contribute to the development of the region, I was offered this job, or decentralization or fusion For interviewees indicated the option "secure job" the variable "security of employment" is codes " 1 " otherwise " 0 ".
} 
extensive policy participation. On average, they desire competence regarding only 1.6 of the twelve policy areas. Although the desire for policy competence is stronger in the other countries, German respondents are still surprisingly modest in their preferences, desiring subnational competence for only 3.4 policies. This picture is noteworthy because the preferences actually lag behind the status quo for German Länder competences. The national mean values for the Polish (4.8) and French (4.3) respondents point to a mid-degree claim for codetermination rights compared to the other country scores. In contrast, Spanish top-level subnational bureaucrats favour regional participation in about eight policy areas, which reflects a desire for strong policy participation within the European multilevel system. ${ }^{21}$ Second, the standard deviations for the countries listed in Table 4 indicate considerable within-country variation as well. In other words, we do find interesting variation within the five countries. What explains such differences among regio-crats' preferences for policy codetermination rights?

Table 4: National mean values for desired policy competence ${ }^{22}$

\begin{tabular}{cccc}
\hline Country & Mean & SD & $N$ \\
\hline Germany & 3.4 & 2.3 & 76 \\
Poland & 4.8 & 2.5 & 65 \\
Hungary & 1.6 & 1.8 & 83 \\
France & 4.3 & 2.0 & 65 \\
Spain & 8.0 & 1.3 & 49 \\
Total & 4.1 & 2.8 & 338 \\
\hline
\end{tabular}

Source: Authors' compilation.

Can the differential desires for policy codetermination be explained by functionality? Looking at the preference patterns of the top-level subnational bureaucrats in regard to the twelve policy areas, we are able to assess whether the administrators form their preferences on the basis of a functionality rationale or not. By comparing the preference patterns for regional policy competences to what we deem would be the objective functional policy allocation, we are able to assess whether or not there is a correlation. If the interviewees favoured regional policy participation regardless of whether or not such codetermination is functional (according to our assessment), we have at least an indication that some other than a functional-efficiency explanation must be at work.

Having carried out the categorisation, we can count for how many policies the answers of our regio-crats are in line with the presumably most efficient allocation. Our result is that the answers of our respondents are substantially in line with functional criteria of competence allocation. Table 5 gives an overview of the share of policies for which the regio-crats' preferences for regional participation (or nonparticipation) are in accordance with the allocation on the basis of functional efficiency. For example, the preferences of about 59 percent of the German interviewees are in line with the functionality rationale for six to eight policies. In France, about 57 percent of our respondents show preferences that correspond with the efficient participation or non-participation of regional authorities for more than eight policies. All in all, in every country we studied, the preferences regarding (non-)participation of subnational authorities of the majority of interviewees correspond with the functional-efficiency expectation. Only a few respondents demonstrate codetermination preferences that clearly conflict with functionality.

\footnotetext{
${ }^{21}$ For a detailed discussion of the preferences regarding policy competences, see Pitschel (2012).

${ }^{22}$ The table shows the mean value of the desired number of policies for regional policy competences. Shown are the mean values (mean) of the preferences, the standard deviation (sd), and the number of respondents $(\mathrm{N})$ for the sample and per country.
} 
Table 5: Correspondence of regio-crats' preferences with functional needs ${ }^{23}$

For how many of the twelve policies do subnational administrators' responses correspond with efficient competence allocation?

\begin{tabular}{ccccccc}
\hline $\begin{array}{c}\text { For less } \\
\text { than 6 } \\
\text { policies }\end{array}$ & Germany & Poland & Hungary & France & Spain & Total \\
$\begin{array}{c}\text { For 6 to 8 } \\
\text { policies }\end{array}$ & 59.2 & 9.2 & 41.0 & 4.6 & 12.2 & 16.3 \\
$\begin{array}{c}\text { For more } \\
\text { than 8 } \\
\text { policies }\end{array}$ & 32.9 & 41.5 & 50.6 & 38.5 & 83.7 & 53.3 \\
\hline
\end{tabular}

Source: Authors' compilation.

Summing up, we observe that the national mean preferences for regional participation in the twelve policies differ across the five countries, with the Spanish having the highest and the Hungarian the lowest scores. At the same time, however, we observe variation within the countries under study. The individuals' preferences concerning the desired extent of regional policy competence vary considerably within the countries. Individual attitudes deviate most around the respective national average in Poland and Germany. To find a reason for this result, we turn to the statistical analysis.

\section{Quantitative Analysis}

Our quantitative analysis assesses how the factors underlying the explanatory approaches are related to the dependent variable, namely the desire for regional codetermination in different policy areas. We basically run three regressions, which differ in the conceptualisation of the dependent variable. The dependent variable of the first model refers to all twelve policies under study. In the second and third models, the dependent variables relate to policies for which (according to our yardstick) regions constitute the functionally appropriate - or non-appropriate governmental level of execution for the policies in our sample. This procedure enables us to detect stable relationships between the independent variables and the subnational administrators' preferences regarding regional policy codetermination. Moreover, we gain knowledge about the influence of policyinherent logics on the process of preference formation. The results of the models are presented in Table 6.

First, the subnational administrators' preferences regarding regional competence are analysed with respect to all twelve policies (Model 1 in Table 6). Concerning the individual-utility variables, only the indicator for safety thinking ("security of employment") is significant. The positive sign is in line with the theoretically expected relationship: Administrators who entered subnational administrations motivated by security of employment are in favour of more subnational competences. As regards the social identity approach, the socioeconomic variable reflecting the regions' economic performance (measured in GDP) shows a negative sign - implying that the desire for subnational competence decreases with regional wealth. In other words, our data show that regio-crats from socioeconomically weaker regions are more in favour of regional policy participation than their colleagues from socioeconomically stronger entities.

Cultural distinctiveness is also influential as a predictor of regional desire for emancipation from the nation state. The positive and significant coefficient of the

\footnotetext{
${ }^{23}$ Percentage of respondents per country for which the preferences for regional policy competences are in line with the functionality principle. Whether participation or non-participation of subnational authorities in policies is functionally efficient was evaluated on the basis of objective criteria (see Table 9 in the Appendix).
} 
variable "stateless nation" indicates that subnational administrators of such regions in our sample (Alsace and Brittany in France, Catalonia and País Vasco in Spain) want to have more subnational policy competences. We also find significant coefficients concerning the indicators of the party-political constellation. On the one hand, the subnational context in which the regional government is "partly in opposition" to the national government or government coalition seems to be negatively related to the desire of the top-level bureaucrats for regional policy competences. In contrast, the individuals from subnational authorities where the regional government is "completely in opposition" to the national government (or governmental coalition) are obviously more in favour of policy participation by their authority. We supposed that the institutional setting would influence the preferences as well. The significant and positive coefficient of the variable "institutional depth" is in line with the theoretical expectation that top-level bureaucrats from institutionally strong regions would desire more codetermination rights over a greater range of policy areas. What also shows a significant and positive coefficient, however, is the variable measuring regional population. This means that the larger the regional population, the more competences are desired by regio-crats. The model including all twelve policies shows a considerably higher degree of variance between the groups (regions) than within the regions. Overall, Model 1 explains about 24 percent of the variance.

Table 6: Regression results for all 12 policies

\begin{tabular}{|c|c|c|c|c|}
\hline $\begin{array}{l}\text { Explanatory } \\
\text { approach }\end{array}$ & Variables & $\begin{array}{c}\text { Model } 1 \\
\text { all } 12 \text { policies }\end{array}$ & $\begin{array}{c}\text { Model } 2 \\
7 \text { functional policies }\end{array}$ & $\begin{array}{c}\text { Model } 3 \\
5 \text { non-functional } \\
\text { policies }\end{array}$ \\
\hline \multirow{2}{*}{$\begin{array}{l}\text { Opportunity } \\
\text { approach }\end{array}$} & career ambitions & $\begin{array}{c}0.043 \\
(0.279)\end{array}$ & $\begin{array}{c}0.041 \\
(0.223)\end{array}$ & $\begin{array}{c}0.002 \\
(0.090)\end{array}$ \\
\hline & $\begin{array}{l}\text { security of } \\
\text { employment }\end{array}$ & $0.969^{*}$ & 0.381 & $0.386^{* *}$ \\
\hline \multirow{5}{*}{$\begin{array}{l}\text { Subnational } \\
\text { social } \\
\text { identity }\end{array}$} & regional gdp & $\begin{array}{c}(0.518) \\
-0.125^{\star *} \\
(0.053)\end{array}$ & $\begin{array}{l}(0.413) \\
-0.069^{\star} \\
(0.037)\end{array}$ & $\begin{array}{c}(0.168) \\
-0.058^{* *} \\
(0.024)\end{array}$ \\
\hline & stateless nation & $\begin{array}{l}2.728^{* * *} \\
(0.833)\end{array}$ & $\begin{array}{l}1.548^{* * *} \\
(0.587)\end{array}$ & $\begin{array}{l}1.229^{* * *} \\
(0.373)\end{array}$ \\
\hline & partly in opposition & $\begin{array}{c}-1.427^{\star \star \star} \\
(0.449)\end{array}$ & $\begin{array}{l}-1.275^{\star \star \star} \\
(0.313)\end{array}$ & $\begin{array}{l}-0.112 \\
(0.204)\end{array}$ \\
\hline & $\begin{array}{l}\text { completely in } \\
\text { opposition }\end{array}$ & $1.410^{*}$ & 0.807 & $0.646^{*}$ \\
\hline & institutional depth & $\begin{array}{l}(0.773) \\
1.521^{\star \star} \\
(0.678)\end{array}$ & $\begin{array}{c}(0.537) \\
0.298 \\
(0.473)\end{array}$ & $\begin{array}{l}(0.352) \\
1.244^{\star \star \star} \\
(0.308)\end{array}$ \\
\hline \multirow{7}{*}{ Control } & $\begin{array}{l}\text { regional population } \\
\text { (log) }\end{array}$ & $0.000^{* *}$ & $0.000^{* * *}$ & 0.000 \\
\hline & constant & $\begin{array}{l}(0.000) \\
2.086^{\star} \\
(1.255)\end{array}$ & $\begin{array}{c}(0.000) \\
3.568^{\star \star \star} \\
(0.877)\end{array}$ & $\begin{array}{c}(0.000) \\
-1.521^{\star \star \star} \\
(0.567)\end{array}$ \\
\hline & \multirow{2}{*}{$\begin{array}{c}\text { observations } \\
\text { number of regions }\end{array}$} & 297 & 297 & 296 \\
\hline & & 57 & 57 & 57 \\
\hline & \multirow[t]{3}{*}{ r-squared } & 0.000 & 0.000 & 0.003 \\
\hline & & 0.446 & 0.446 & 0.362 \\
\hline & & 0.243 & 0.182 & 0.315 \\
\hline
\end{tabular}

Source: Authors' compilation. Note: Standard errors in parentheses; ${ }^{* * *} p<0.01,{ }^{* *} p<0.05,{ }^{*} p<0.1$.

Second, we analysed only those policies that can be deemed efficiently regulated at the subnational level (Model 2 in Table 6). ${ }^{24}$ Whereas the individual variables of the opportunity model seem not to be influential at all, the social identity variables show similar patterns to the first model. The "regional gdp" variable is once again negative and significant. Similarly, the "stateless nation" variable is significant and

\footnotetext{
${ }^{24}$ These policies are social affairs, health care and consumer protection, culture and education, tourism, environmental protection, research and technology, and economic development and structural policy. The reasons for this classification are explained in Table 9 in the Appendix.
} 
has a positive sign, as in the preceding model. With respect to the party-political situation, only the variable "partly in opposition" maintains its negative and significant coefficient in this model. In contrast, the variable "completely in opposition" is insignificant in Model 2. The same is true for the regional authority variable "institutional depth". Neither "fiscal autonomy" nor "regional representation" show a significant coefficient. Finally, the regional population size repeatedly demonstrates a positive and significant coefficient. Comparing the variance explained by this model to the first model, we do not find any enhancement, neither in the explanation of the individual-level variance nor in the explanation of the between variance. However, the overall explained variance of the model on those policies that are efficiently regulated at the regional level is lower than in the model including all twelve policies (Model 1).

Finally, we assess the explanatory programmes with respect to those policies in our sample that are supposedly not efficiently regulated at the regional level (see Model 3 in Table 6 ). ${ }^{25}$ This variant of the dependent variable might be an interesting case for both the opportunity and the subnational identity approaches. Do such variables influence the preference for regional policy competence although such participation is not efficient? In this third model, the individual variable of the opportunity explanatory program "career ambition" again shows no significant and positive coefficient. In contrast, the variable "security of employment" regains its theoretically expected positive sign.

The subnational identity approach variables perform comparably to the second model. The "regional gdp" variable shows a negative and significant coefficient. The better the socioeconomic situation concerning GDP, the less policy competences are desired by regio-crats. The variable indicating that a region represents a stateless nation is positive and significant, as expected. The same holds for the political variable "completely in opposition", which reflects the situation where the regional governmental coalition is incongruent with the party-political constellation in national government. Again, we see our expectation of a positive relationship between this variable and the desire for more regional competences confirmed. The variable "partly in opposition", however, is not significant. Concerning the aspect of regional autonomy, we find that subnational administrators from regions which are institutionally well endowed favour more policy competences.

The variance between the units explained by the regression model is lower than in the other two models. Model 3 explains about 36 percent of the variance between the regions. Compared to Model 1 and 2 this proportion is lower. In contrast, with regard to the overall variance, we find a high proportion is explained by Model 3 (about 32 percent).

Discussing the regression results in the context of non-functional policies, we believe this is evidence that subnational administrators' preference formation is based on an opportunity rationale. Personal interest in secure employment in the regional administration is influential not only in the first model, comprising all twelve policies, but also in third model, which concentrates on those policies that are not efficiently regulated at the regional level. As regards the emancipatory ambitions of regional authorities, which are supposed to be the driving force in the social identity approach, we find some evidence to confirm the theoretical reasoning. Whereas the picture is clear for those administrators from culturally distinct regions who favour more policy competences, the influence of the political situation is less evident. In contrast, we find unambiguous results for the influence of the

\footnotetext{
25 These policies are asylum and immigration, foreign affairs and defence, border police and frontier defence, agriculture, and monetary policy. The reasons for this classification are explained in Table 9 in the Appendix.
} 
institutional setting ("institutional depth") on the extent of regional policy participation.

Summing up, the results of our quantitative analysis are consistent. The significant variables do not change their signs in the different models and we find the theoretical expectations generally confirmed. However, some points have to be reinvestigated in more detail. This applies, in particular, to the influence of the party-political constellation of the regions compared to the situation at the central state level. On the one hand, we find the expected relationship for the case when the regional government is not congruent with the party-political constellation of the central government. On the other hand, the opposite is true for the case where the regional government is partly in opposition at the national level. This contradicts the theoretical expectation and requires further investigation.

\section{Conclusion}

Two sets of conclusions can be drawn from this study. The first concerns the insights our analysis is able to generate in view of the question as to how to explain regio-crats' preferences regarding policy participation in the multilevel system. Notwithstanding bold statements in the relevant literature, the desire for subnational policy codetermination is astonishingly low throughout our sample. Regio-crats cannot be seen as "competence conquerors" that fuel state transformation by demanding ever greater policy involvement. Quite the contrary, regio-crats appear in this respect to be rather conservative. There is little reason to fear (or hope, depending on the perspective) that regions will shake up the existing competence distribution; the suspicion that regions will actively ask for ever greater policy involvement cannot be substantiated by our data. Instead, the preferences seem to a large extent based on a rationale of functionality. The big picture is that regio-crats' policy participation demands are in harmony with what can be conceived as objectively efficient vertical competence allocation.

On a smaller scale, however, the statistical analyses show that besides individual utility aspects, variables that are related to regional emancipatory ambitions also have a positive influence on the desire for more policy competence. Cultural and political distinctiveness (in comparison to the situation at the central state level) increase the demand for regional policy involvement. In other words, a large-scale and uniform transformation in the direction of a Europe of the regions is unlikely. Pressure for greater regional policy involvement is differential and its direction and magnitude depend on particular regional situations. On the basis of our analysis, we do not expect demands for regional policy involvement to be systemic and systematic, but disorderly, disparate and diverse. Regional policy participation demands in the multilevel system are pragmatic, patch-worked and incremental and more conservative than transformative.

\section{References}

Alesina, Alberto and Enrico Spolaore (2003) The Size of Nations, Cambridge, MA: MIT Press.

Alesina, Alberto, Ignazio Angeloni and Ludger Schuknecht (2001) 'What Does the European Union Do?' National Bureau of Economic Research Working Paper No. 8647, Washington DC.

Bauer, Michael W. (2008) 'Diffuse Anxieties, Deprived Entrepreneurs. Commission Reform and Middle Management', Journal of European Public Policy, 15(5): 691707.

Bauer, Michael W, Diana Pitschel and Philipp Studinger (2010) 'Governance Preferences of Subnational Administrative Elites in the European Union. An 
Empirical Analysis', Lehrstuhl für Politik und Verwaltung Working Paper No. 4, 2010, HU Berlin.

Benz, Arthur. (2007) 'Politischer Wettbewerb', in A. Benz, S. Lütz, U. Schimank and G. Simonis (eds), Handbuch Governance. Theoretische Grundlagen und empirische Anwendungsfelder. Wiesbaden: VS Verlag, 54- 67.

Benz, Arthur. and Christina Zimmer (2008) 'The EU's Competences: The "Vertical" Perspective on the Multilevel System', Living Reviews in European Governance 3(3). URL (consulted 30 Nov. 2008) : http://www.livingreviews.org/lreg-2008-3.

Bird, Richard, Bernard Dafflon, Claude Jeanrenaud and Gebhard Kirchgässner (2002) 'Assignment of Responsibilities and Fiscal Federalism', in Raoul Blindenbacher and Arnold Koller (eds) Conference Reader of the International Conference on Federalism 2002: Federalism in a Changing World Learning from Each Other, Quebec: McGill-Queen's University Press.

Björklund, Fredrika. (2006) 'The East European Ethnic Nation - Myth or Reality?' European Journal of Political Research, 45(1): 93-121.

Bookman, Milika Z. (1992) The Economics of Secession. New York: St. Martin's Press.

Brancati, Dawn. (2006) 'Decentralization: Fueling the Fire or Dampening the Flames of Ethnic Conflict and Secessionism?' International Organization, 60(3): 651-85.

Connor, Walker (1994) Ethnonationalism. Princeton, NJ: Princeton University Press.

De Vries, Catherine E. and Kees van Kersbergen (2007), 'Interests, Identity and Political Allegiance in the European Union', Acta Politica, 42(2-3), 307-28.

Diez Medrano, Juan (2003) Framing Europe: Attitudes to European Integration in Germany, Spain and the United Kingdom. Princeton: Princeton University Press.

Dunleavy, Patrick (1985) 'Bureaucrats, Budgets and the Growth of State: Reconstructing an Instrumental Model', British Journal of Political Science, 15(3): 299-328.

Egeberg, Morten (2004) 'An organisational approach to European integration: Outline of a complementary perspective', European Journal of Political Research, 43(2): 199-219.

Esman, Milton J. (1977) 'Perspectives on Ethnic Conflict in Industrialized Societies', in Milton J. Esman (ed.) Ethnic Conflict in the Western World, pp. 371-90. Ithaca: Cornell University Press:

Fearon, James D. and Pieter van Houten (2002). 'The Politicization of Cultural and Economic Difference. A Return to the Theory of Regional Autonomy Movements'. Paper presented at the Fifth Meeting of the Laboratory in Comparative Ethnic Processes (LiCEP), Stanford University, 10-11 May.

Gourevitch, Peter A. (1979) 'The Re-emergence of "Peripheral Nationalisms": Some Comparative Speculations on the Spatial Distribution of Political Leadership and Economic Growth', Comparative Studies in Society and History, 21(3): 303-22.

Harvie, Christopher (1994) The Rise of Regional Europe. London: Routledge.

Hechter, Michael. (1975) Internal Colonialism: The Celtic Fringe in British National Development, 1536-1966. Berkeley, CA: University of California Press.

Hoeller, Peter, Marie-Odile Louppe and Patrice Vergriete (1996) 'Fiscal Relations within the European Union', OECD Economic Department Working Paper No. 163, Paris: OECD Publishing. 
Hooghe, Liesbet. (1995) 'Subnational Mobilisation in the European Union', West European Politics, 18(3): 175-98.

Hooghe, Liesbet. (2001) The European Commission and the Integration of Europe. Images of Governance, Cambridge: Cambridge University Press.

Hooghe, Liesbet (2003) 'Europe Divided? Elites vs. Public Opinion on European Integration', European Union Politics, 4(3): 281-304.

Hooghe, Liesbet and Gary Marks (2005) 'Calculation, Community and Cues: Public Opinion on European Integration', European Union Politics, 12(1): 419-43.

Hooghe, Liesbet. and Gary Marks (2009) 'Does Efficiency Shape the Territorial Structure of Government?' Annual Review of Political Science, 12(1): 225-41.

Hooghe, Liesbet, Gary Marks and Arjan H. Schakel (2010) The Rise of Regional Authority. A Comparative Study of 42 Democracies, Abingdon: Routledge.

Jeffery, Charlie (1996) 'Conclusions: Sub-national authorities and 'European domestic policy', Regional and Federal Studies, 6(2): 204-19.

Jeffery, Charlie (2000) 'Sub-National Mobilization and European Integration: Does it Make Any Difference?', Journal of Common Market Studies, 38(1): 1-23.

Jeffery, Charlie and Daniel Wincott (2010) 'The Challenge of Territorial Politics: Beyond Methodological Nationalism', in Colin Hay (ed.) New Directions in Political Science: Responding to the Challenges of an Interdependent World, Basingstoke: Palgrave Macmillan, 167-88.

Kato, Junko (1996) 'The Challenge of Territorial Politics: Beyond Methodological Nationalism', British Journal of Political Science, 26(4): 553-82.

Keating, Michael (1998) The New Regionalism in Western Europe. Territorial Restructuring and Political Change. Cheltenham: Edward Elgar.

Keating, Michael (2008) 'A Quarter Century of the Europe of the Regions', Regional and Federal Studies, 18(5): 629-35.

Levi, Margaret (1997) 'A Model, a Method and a Map: Rational Choice in Comparative and Historical Analysis', in Mark I. Lichbach and Allan S. Zuckerman (eds), Comparative Politics: Rationality, Culture and Structure, Cambridge: Cambridge University Press, 19-41.

Loveless, Matthew and Robert Rohrschneider, R. (2008) 'Public Perceptions of the EU as a System of Governance', Living Reviews in European Governance, 3 (1). Online. Available from: http://www.livingreviews.org//reg-2008-1, (accessed 19 December 2008).

Marks, Gary, François Nielsen, Leonard Ray and Jane E. Salk (1996) 'Competences Cracks and Conflicts: Regional Mobilization in the European Union', Comparative Political Studies, 19(2): 164-92.

McLaren, Lauren M. (2002) 'Public Support for the European Union: Cost/Benefit Analysis or Perceived Cultural Threat?', Journal of Politics, 64(2): 551-66.

Niskanen, William .A. (1971) Bureaucracy and Representative Government. New York: Aldine-Atherton.

Oates, Wallace E. (1999) 'An Essay on Fiscal Federalism', Journal of Economic Literature, 37(3): 1120-49.

Oberhofer, Julia, Julia Stehlin and Roland Sturm (2011) 'Citizenship im unitarischen Bundesstaat', Politische Vierteljahresschrift, 52(2): 163-194

Olsen, Johan P. (2009) 'Change and Continuity: an institutional approach to institutions of democratic government', European Political Science Review, 1(1): 332. 
Pitschel, Diana (2012) Europa mit den Regionen? Eine empirische Analyse der Kompetenzbeteiligung von Regionen im europäischen Mehrebenensystem. BadenBaden: Nomos.

Schakel, Arjan H. (2009) 'Explaining Policy Allocation Across Government Tiers by Identity and Functionality', Acta Politica, 44(4): 385-409.

Schakel, Arjan H. (2010) 'Explaining Regional and Local Government: An Empirical Test of the Decentralization Theorem', Governance: An International Journal of Policy, Administration and Institutions, 23(2): 331-55.

Scully, Roger and David Farrell (2003) 'MEPs as Representatives: Individual and Institutional Roles', Journal of Common Market Studies, 41(2): 269-288.

Searing, Donald D. (1991) 'Roles, Rules and Rationality in the New Institutionalism', American Political Science Review, 85(4): 1239-60.

Searing, Donald D. (1994) Westminster's World. Understanding Political Roles. Cambridge, MA: Harvard University Press.

Seeman, Melvin (1993) 'A Historical Perspective on Attitude Research', in Dagmar Krebs and Peter Schmidt (eds), New Directions in Attitude Measurement, Berlin: Walter de Gruyter, 3-20.

Shah, Anwar (2002) 'Fiscal Decentralization in Transition Economies and Developing Countries - Progress, Problems and the Promise', paper presented at the International Conference "Federalism in a Changing World - Learning From Each Other", St. Gallen, 27 - 30 August.

Shah, Anwar (2007) 'Introduction: Principles of Fiscal Federalism', in idem. (ed.) The Practice of Fiscal Federalism: Comparative Perspectives. Montreal: McGillQueen's University Press, 3-43.

Sinn, Hans-Werner. (2003) The New Systems Competition. Oxford: Basil Blackwell.

Smekal, Christian (2001) 'Zentralisation und Dezentralisation öffentlicher Aufgabenerfüllung aus finanzwissenschaftlicher Sicht', in Peter Pernthaler and Peter Bußjäger (eds) Ökonomische Aspekte des Föderalismus, Schriftenreihe des Instituts für Föderalismus, pp. 69-76. Vienna: Braumüller.

Tatham, Michael (2008) 'Going Solo: Direct Regional Representation in the European Union', Regional and Federal Studies, 18(5): 493-515.

Ter-Minassian, Teresa (1997) 'Intergovernmental Fiscal Relations in a Macroeconomic Perspective: An Overview', in Teresa Ter-Minassian (ed.) Fiscal Federalism in Theory and Practice, pp. 3-24. Washington: IMF.

Thielemann, E.R. (2004) 'Dividing Competences: Germany's Vision(s) for Europe's Federal Future', Comparative European Politics, 2(3): 358-74.

Tömmel, Ingeborg (2008) 'Governance und Policy-Making im Mehrebenensystem der EU', in Ingeborg Tömmel (ed.) Die Europäische Union - Governance und Policy-Making, PVS-Sonderheft, pp. 13-35. Wiesbaden: VS Verlag für Sozialwissenschaften.

Van Esch, Femke (2006) 'The Europeanization of Central Decision Makers' Preferences Concerning Europe. A Perpetual Motion?', in Ronald Holzhacker and Markus Haverland (eds) European Research Reloaded: Cooperation and Integration among Europeanized States, pp. 119-49. Berlin: Springer.

Van Houten, Pieter. (2003) 'Globalization and Demands for Regional Autonomy in Europe', in Miles Kahler and David A. Lake (eds) Governance in a Global Economy. Political Authority in Transition, pp. 110-35. Princeton, NJ: Princeton University Press. 
Van Houten, Pieter (2009) 'Multi-Level Relations in Political Parties. A Delegation Approach', Party Politics, 15(2): 137-56. 


\section{Appendix}

Table 7: Overview of regions represented in the sample

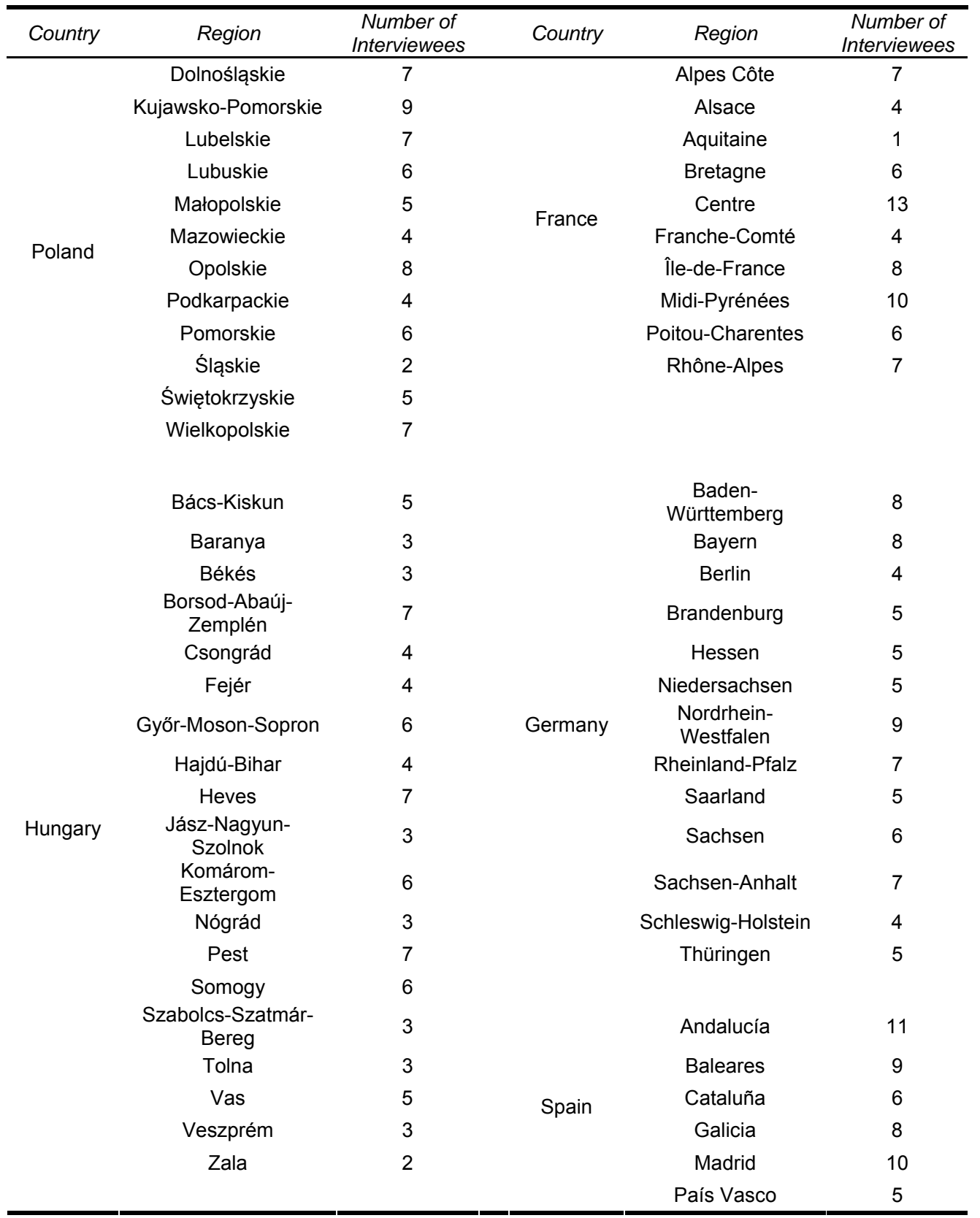

Table 8: Independent variables

\begin{tabular}{|c|c|c|c|c|}
\hline Variable & $\begin{array}{c}\text { Level of } \\
\text { measurem } \\
\text { ent }\end{array}$ & Operationalisation & Coding & $\begin{array}{c}\text { Expected } \\
\text { sign }\end{array}$ \\
\hline & & Interviewee wants to advance & & \\
\hline career ambitions & & $\begin{array}{c}\text { his career within the } \\
\text { subnational administration. }\end{array}$ & $1=$ yes, $0=$ no & + \\
\hline $\begin{array}{l}\text { security of } \\
\text { employment }\end{array}$ & Individual & $\begin{array}{l}\text { Interviewee is motivated by } \\
\text { the security of employment } \\
\text { within the subnational } \\
\text { administration. }\end{array}$ & $1=$ yes, $0=$ no & + \\
\hline regional gdp & $\begin{array}{c}\text { Subnation } \\
\text { al }\end{array}$ & Gross Domestic Product & Gross Domestic & $-1+$ \\
\hline
\end{tabular}




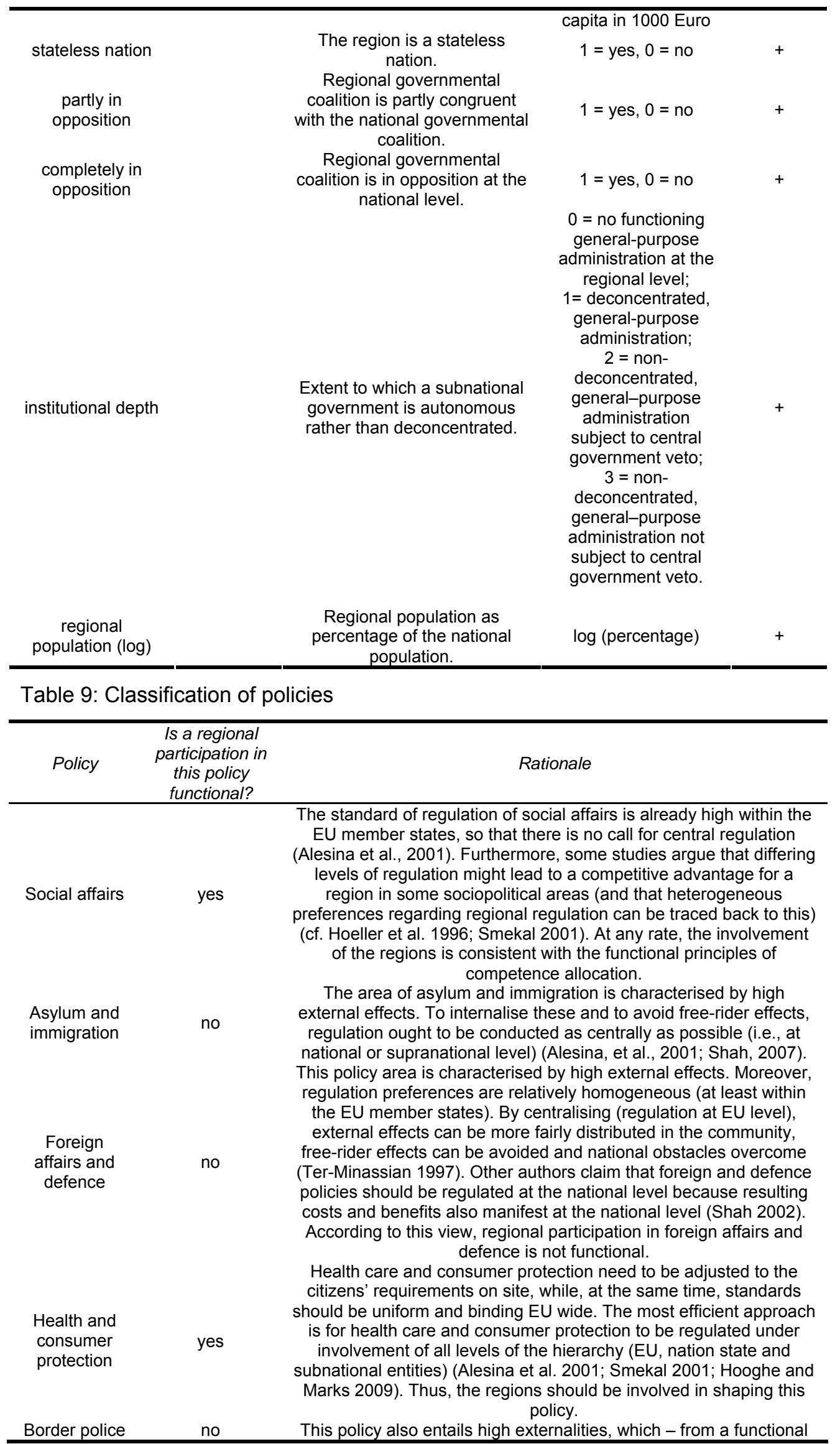




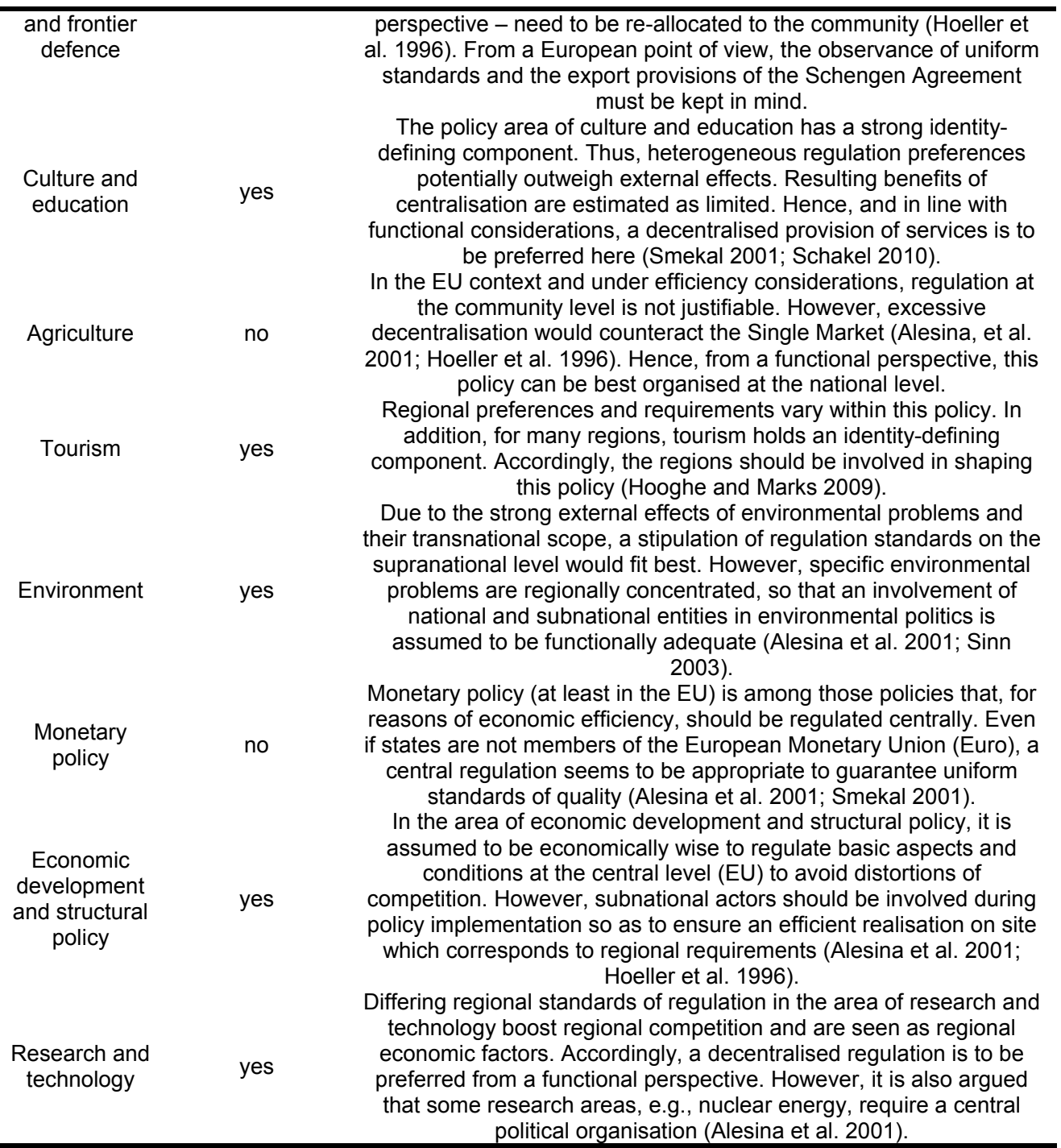

